\title{
Burden of Community-Acquired Pneumonia and Unmet Clinical Needs
}

\author{
João Ferreira-Coimbra (ib $\cdot$ Cristina Sarda $\cdot$ Jordi Rello
}

Received: October 23, 2019 / Published online: February 18, 2020

(c) The Author(s) 2020

\begin{abstract}
Community-acquired pneumonia (CAP) is the leading cause of death among infectious diseases and an important health problem, having considerable implications for healthcare systems worldwide. Despite important advances in prevention through vaccines, new rapid diagnostic tests and antibiotics, CAP management still has significant drawbacks. Mortality remains very high in severely ill patients presenting with respiratory failure or shock but is
\end{abstract}

Enhanced Digital Features To view enhanced digital features for this article go to https://doi.org/10.6084/ m9.figshare.11673588.

J. Ferreira-Coimbra ( $₫)$

Internal Medicine Department, Centro Hospitalar

Universitário do Porto, Porto, Portugal

e-mail: joaoferreiracoimbra@gmail.com

C. Sarda

Infectious Diseases Department, Fondazione IRCCS

Policlinico San Matteo, Pavia, Italy

J. Rello

Clinical Research/Epidemiology in Pneumonia and Sepsis (CRIPS), Vall d'Hebron Institute of Research, Barcelona, Spain

J. Rello

CIBERES-Centro de investigación en red de

enfermedades respiratorias, Madrid, Spain also high in the elderly. Even after a CAP episode, higher risk of death remains during a long period, a risk mainly driven by inflammation and patient-related co-morbidities. CAP microbiology has been altered by new molecular diagnostic tests that have turned viruses into the most identified pathogens, notwithstanding uncertainties about the specific role of each virus in CAP pathogenesis. Pneumococcal vaccines also impacted CAP etiology and thus had changed Streptococcus pneumoniae circulating serotypes. Pathogens from specific regions should also be kept in mind when treating CAP. New antibiotics for CAP treatment were not tested in severely ill patients and focused on multidrug-resistant pathogens that are unrelated to CAP, limiting their general use and indications for intensive care unit (ICU) patients. Similarly, CAP management could be personalized through the use of adjunctive therapies that showed outcome improvements in particular patient groups. Although pneumococcal vaccination was only convincingly shown to reduce invasive pneumococcal disease, with a less significant effect in pneumococcal CAP, it remains the best therapeutic intervention to prevent bacterial CAP. Further research in CAP is needed to reduce its population impact and improve individual outcomes.

Keywords: CAP; Community-acquired pneumonia; Epidemiology; Infectious disease 
Key Summary Points

Community-acquired pneumonia (CAP) is a major health concern, because it is a very frequent and deadly condition.

CAP etiology is changing owing to the recognized importance of viruses, pneumococcal and influenza vaccines.

New drugs were developed to treat CAP; however, most of them focus on nonsevere CAP.

Despite the frequency of CAP, several recommendations are based on low quality evidence. We have therefore defined several unmet clinical needs to promote research on CAP.

\section{INTRODUCTION}

Community-acquired pneumonia (CAP) is a frequent and deadly infection, having considerable implications for healthcare systems worldwide. CAP is responsible globally for 3 million deaths annually [1]. Poor outcomes are usually related to CAP severity and patient characteristics and co-morbidities.

Some recent advances emphasise in the importance of continuous research in CAP. CAP classification has varied over the last 20 years. Recently, American guidelines [2] abandoned healthcare-associated pneumonia (HCAP) because of the lack of evidence showing differences in microbiology of CAP and HCAP. This definition change could introduce differences in epidemiological reporting. Important advances in CAP have also been reported since pneumococcal vaccines and diagnostic tests for viruses. Recently, Nature Medicine published the first use of phages to treat a multidrug-resistant (MDR) microorganism [3] and Lancet Infectious Diseases reported the first use of pneumolysin in severe CAP treatment added to standard of care in a phase II trial [4]. These advances emphasise the importance of continuously updating CAP management and research and development.

In this review, we aim to provide a perspective of CAP burden that is critical to allocating resources to improve patient outcomes and also to support new research focused on unmet clinical needs. This article is based on previously conducted studies and does not contain any studies with human participants or animals performed by any of the authors.

\section{BURDEN OF COMMUNITY- ACQUIRED PNEUMONIA}

\section{CAP Incidence}

In Europe, CAP incidence varies widely ranging from 20.6/10,000 in Iceland [5] to 79.9/ 10,000 person-years in the UK [6]. Data from Italy [7] in adults (over 15 years of age) between 2005 and 2019 reported CAP incidence between 29.3 and 30.6 per 10,000 inhabitants and a hospitalization rate lower than $10 \%$ within 60 days from diagnosis. In France, CAP incidence is estimated as 47 per 10,000 person-years [8] with $7 \%$ of patients being admitted in the 30-day period after CAP diagnosis.

In the USA, in adults under 65 years old, CAP incidence varies between 24.8/10,000 personyears [9] and 106/10,000 person-years [10]. Moreover, as expected, elderly people have a higher incidence, representing 63.0/ 10,000 person-years in 65-79-year-olds and reaching 164.3/10,000 person-years after 80 years old. A study in Latin America (including Argentina, Paraguay and Uruguay) reported incidence varying between 4.8 and $110 / 10,000$ person-years in people aged 18-64 years and 109-294/10,000 person-years in those over 65 years [11]. Another study in Latin America (Argentina, Brazil, Chile, Colombia, Mexico and Venezuela) reported CAP incidence varying between 32.6 and $80.4 / 10,000$ personyears in a population over 50 years [12].

South Korea has an incidence rate of 62.6/ 10,000 person-years [13] with high importance of pneumococcal pneumonia [14]. CAP incidence in Japan in middle-aged adults (55-64 years) is $65 / 10,000$ person-years, increasing 
markedly over age to 169 and 434/10,000 person-years in adults aged 65-74 years and 75-84 years, respectively. A recent study of three Asian countries [15] reported that CAP is responsible for $1424.5,420.5$ and 98.8 episodes per 10,000 discharges in the Philippines, Indonesia and Malaysia, respectively. In China, CAP incidence is estimated as $29.8-221.0$ per 10,000 admissions including children [16]. In Australia, a study between 2011 and 2013 reported an incidence of 24.5/10,000 personyears [17] in patients older than 20 years. An Australian study estimated CAP incidence in all age groups (including children) as 161.3/ 10,000 , rising to $319.3 / 10,000$ and $659.9 /$ 10,000 person-years in patients between 65 and 74 years and over 75 years, respectively [18]. A retrospective analysis in New Zealand estimates CAP incidence as $85 / 10,000$ in the general population and $188.2 / 10,000$ in patients older than 65 years [19]. Table 1 summarizes global data on CAP incidence in adults.

To properly analyze this data it is important to keep in mind that the real clinical incidence of CAP is difficult to determine because of differences in reporting and case selection from epidemiological studies. CAP notification is optional even in developed countries, except when presenting as invasive pneumococcal disease (when CAP is accompanied by the identification of pneumococcus in sterile fluids such as blood, cerebrospinal fluid, and pleural, joint or peritoneal fluid) and Legionnaires disease in some countries. Worldwide differences in access to healthcare services also preclude direct comparison of incidence [20]. Furthermore, scarce data are available from primary care or representing patients treated in ambulatory settings. Moreover, CAP incidence varies considerably according to geographic location, study methods, case definition and study population [21, 22]. CAP incidence varies and is also highly influenced by age and co-morbidities (such as chronic obstructive pulmonary disease, diabetes mellitus, renal failure, congestive heart failure, coronary artery disease and liver disease). A seasonal effect that doubles the rate of pneumonia in the winter months impacts, additionally, incidence studies [23].

\section{CAP Mortality}

According to the World Health Organisation (WHO) data, lower respiratory tract infections are the primary infective cause of death globally accounting for $6.1 \%$ of deaths [24]. The Global Burden of Disease 2016 Study showed that deaths from low respiratory tract infections decreased both in the total number of deaths $8.2 \%(95 \%$ UI, $-12.4,-3.9)$ and age-standardized rates $22.4 \%$ (95\% UI, - 25.3, - 18.9), from 2006 to 2016 [25]. In the USA, CAP causes around 102,000 deaths per year, a mortality of $13 \%, 23.4 \%$ and $30.6 \%$ at 1 month, 6 months and 12 months, respectively [26]. CAP alone is responsible for at least 23,000 deaths annually in Europe [27]. One-year CAP mortality in Canada is estimated as $28 \%$ [28]. In the Asia-Pacific region CAP mortality is estimated between $1.1 \%$ and 30\% [29]. In low-income countries, mortality tends to be higher, as proved in a study addressing mortality in lowincome countries that showed higher mortality than in high-income countries, reporting a mortality rate of $23 \%$ in Cambodia, $19 \%$ in Senegal, $18 \%$ in Uganda and $16 \%$ in the Central African Republic [30].

Mortality occurs largely in hospitalized patients $(6-20 \%)[22,26,31]$, but it varies widely according to treatment setting and severity disease, while mortality in primary care and ambulatory patients is inferior to $1 \%$ in most of the population, rising in patients over 65 years [7, 8]. One-ninth of patients hospitalized with CAP will need intensive care unit (ICU) admission because of severe respiratory failure, severe sepsis, or septic shock $[32,33]$ and CAP mortality in these patients remains very high, reaching near 50\% [32]. A progressively higher incidence of severe CAP was reported in ICU, but the mortality rate had decreased by $18 \%$ over a 15 -year period [34]. Data reporting on severity could be driven by reimbursement and, therefore, not represent a real increase in severity CAP. Patients who had been treated in the hospital for CAP have a clinically significant long-term poor survival when compared to matched controls. This increased post-discharge mortality is driven by pulmonary complications, new CAP episodes and cardiovascular 


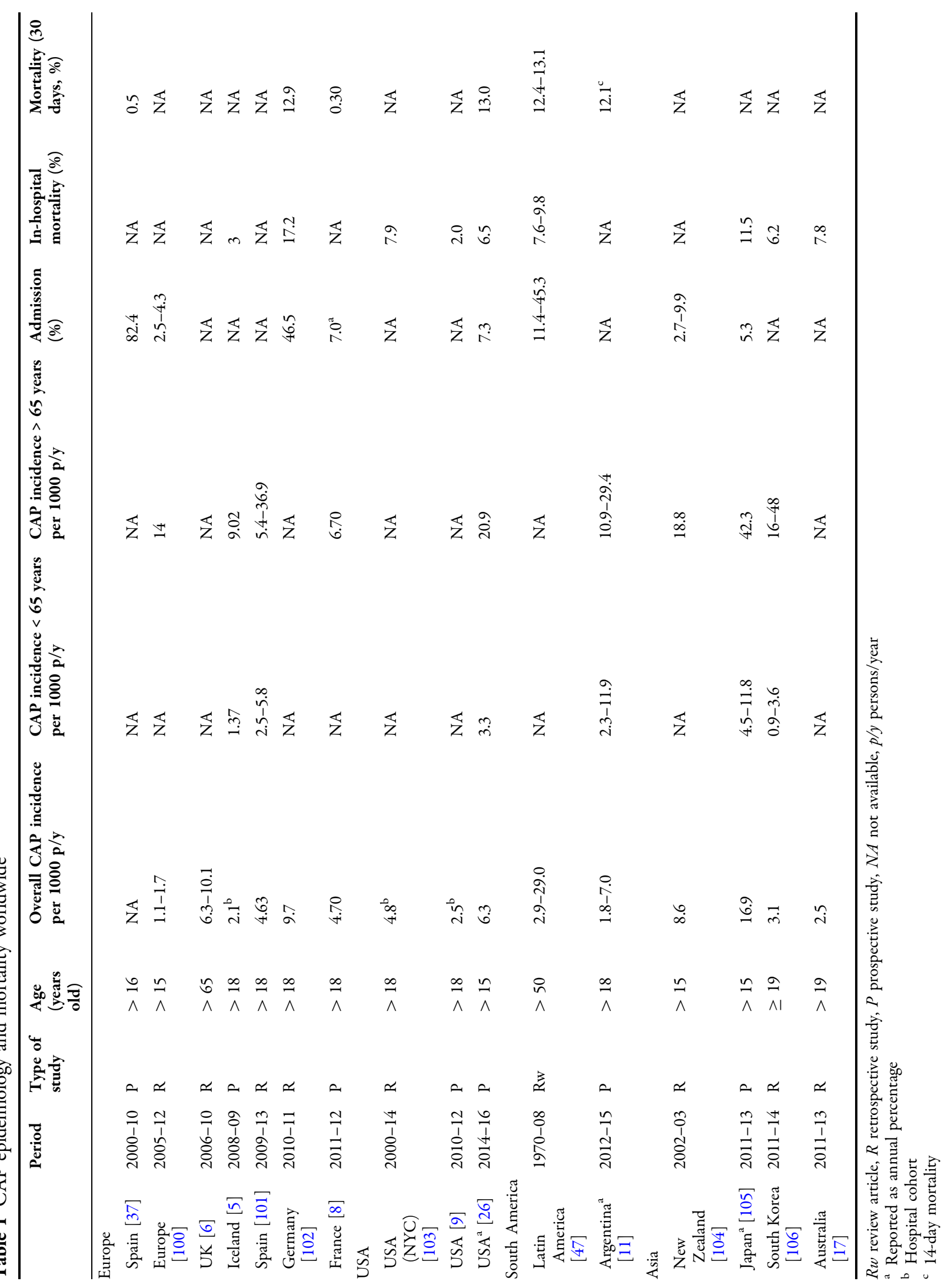


events, probably in the course of a persistent inflammatory response [32, 35].

CAP mortality reflects the enrollment of different patient populations in epidemiological studies as well as their methodology. Hospital and ICU admission criteria vary among different countries and hospitals, which hinders a comparison between them. Different admission criteria across countries, as well as the availability of ICU dedicated beds, technological and human resources could change reported mortality, as well as data regarding ICU admission. Other factors such as guideline adherence and quality of care could also reduce mortality [36]. This data is infrequently reported in epidemiological studies. Numerous patient risk factors and co-morbidities can hardly affect disease severity as well as the risk of death. Patient risk factors age, co-morbidities and immune status, together with microbiological pathogens and the absence of response to treatment also influence mortality [23].

\section{CAP MICROBIOLOGY}

Despite most of CAP episodes being caused by few microorganisms, several bacteria, viruses and fungi are recognized as causes of CAP. However, even when prospective studies were performed, less than half of patients presenting with CAP had a microbiologic diagnosis [9, 37-39]. Important variations are found according to patient severity and used diagnostic tools. The emergence of new diagnostic tests improved the recognition of pathogens compared with previous tests [40], not only for viruses but also for bacterial pathogens, allowing earlier directed therapy and antibiotic deescalation. A higher rate of microorganism isolation was reported when newer diagnostic approaches and molecular techniques were used [39-41]. Some of these approaches are not widely available in clinical practice and their use remains controversial because no studies prove their outcome benefits and tests are costly. Moreover, antiviral agents are inactive against some viruses which precludes the utility of viral identification in clinical practice.
Streptococcus pneumoniae remains the most isolated bacterial pathogen in CAP worldwide in all treatment settings (outpatient, general ward and ICU) [37, 39, 40, 42-46]. S. pneumoniae resistance patterns remain different across countries. In recent studies, Mycoplasma pneumoniae, Chlamydia pneumoniae and Legionella pneumophila, which are well-established causes of CAP, have been isolated more frequently than before $[19,22,47,48]$ (Table 2). However, except for L. pneumophila, the diagnosis is difficult in clinical practice but could improve with multiplex PCR tests. Haemophilus influenzae account for $1.2-19 \%[49,50]$ of all cases of bacterial CAP; however, this rose to around 50\% in some studies [40]. H. influenzae is a major public health problem because of its increasing antimicrobial resistance. Given this resistance, specially to beta-lactams, $H$. influenzae was listed in the priority list of WHO antibiotic-resistant bacteria [51].

Unlike in other global areas, Gram-negative pathogens are also frequent pathogens (mostly Klebsiella pneumoniae and Burkholderia pseudomallei) in Asia. Meloidosis is a life-threatening infectious disease (caused by B.pseudomallei) that is endemic in South and Southeast Asia, northern Australia and China, peaking in the wet season. In some places, it is the third most common deadly disease after HIV and tuberculosis. Pneumonia is the most frequent presentation, with a mortality rate reaching 21\% $[52,53]$, related to shock and bacteremia. Several cases are also reported in travellers returning from endemic areas [54, 55].

Even subject to some variations, generally methicillin-resistant S. aureus and MDR Gramnegative bacilli together cause CAP in approximately $5 \%$ of patients $[56,57]$, presenting even lower incidence in non-critically ill patients. While their empirical coverage is almost always unnecessary in CAP, in some areas and in patients with specific risk factors it could be considered; thus, inappropriate therapy is related to increasing mortality.

The precise role of viruses in CAP is not yet well established e.g. pathogens, co-pathogens, triggers or all-in-one. Respiratory viruses are isolated in up to one-third of patients with CAP [58-60]. However, it is not straightforward to 


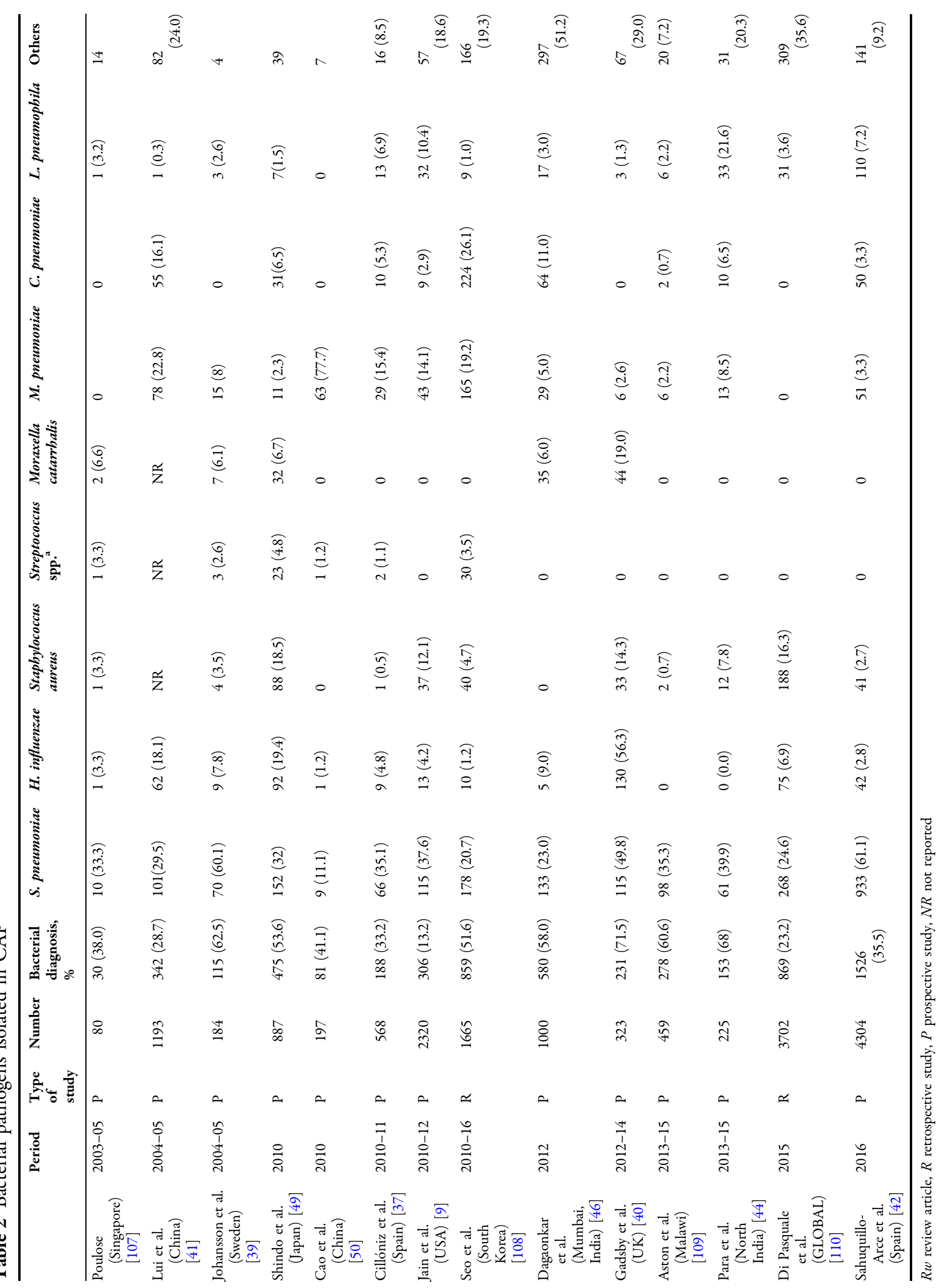


Table 3 Viral pathogens isolated in CAP

\begin{tabular}{|c|c|c|c|c|c|c|c|}
\hline & Period & Number & $\begin{array}{l}\text { Influenza } \\
\text { viruses, } \\
n(\%)\end{array}$ & $\begin{array}{l}\text { Rhinovirus, } \\
n(\%)\end{array}$ & $\begin{array}{l}\text { Respiratory } \\
\text { syncytial virus, } \\
n(\%)\end{array}$ & $\begin{array}{l}\text { Parainfluenza } \\
\text { viruses, } n(\%)\end{array}$ & $\begin{array}{l}\text { Other } \\
\text { respiratory } \\
\text { viruses, } n(\%)\end{array}$ \\
\hline $\begin{array}{l}\text { Lui et al. } \\
\qquad \text { (China) [41] }\end{array}$ & 2004-05 & 1193 & $102(8.5)$ & NR & NR & NR & 0 \\
\hline $\begin{array}{l}\text { Johansson et al. } \\
\text { (Sweden) [39] }\end{array}$ & 2004-05 & 184 & $14(7.6)$ & $12(6.5)$ & $7(3.8)$ & $7(3.8)$ & 0 \\
\hline $\begin{array}{l}\text { Cao et al. } \\
\text { (China) [50] }\end{array}$ & 2010 & 197 & $9(4.6)$ & $2(1.0)$ & $2(1.0)$ & $4(2.0)$ & $7(3.5)$ \\
\hline $\begin{array}{l}\text { Cillóniz et al. } \\
\text { (Spain) [37] }\end{array}$ & $2010-11$ & 568 & $16(2.8)$ & $6(1.1)$ & $1(0.2)$ & $1(0.2)$ & $1(0.2)$ \\
\hline $\begin{array}{l}\text { Jain et al. (USA) } \\
{[9]}\end{array}$ & $2010-12$ & 2259 & $132(5.8)$ & $194(8.6)$ & $68(3.0)$ & $67(3.0)$ & $173(7.7)$ \\
\hline $\begin{array}{l}\text { Seo et al. (South } \\
\text { Korea) }[108]\end{array}$ & $2010-16$ & 1665 & $15(0.9)$ & $2(0.1)$ & $2(0.1)$ & $2(0.1)$ & $6(0.4)$ \\
\hline $\begin{array}{l}\text { Gadsby et al. } \\
\text { (UK) [40] }\end{array}$ & $2012-14$ & 323 & $23(7.1)$ & $41(12.7)$ & $4(1.2)$ & $11(3.4)$ & $19(5.9)$ \\
\hline $\begin{array}{l}\text { Aston et al. } \\
\text { (Malawi) } \\
{[109]}\end{array}$ & $2013-15$ & 459 & $40(8.8)$ & $17(3.7)$ & $8(1.7)$ & $17(3.7)$ & $98(21.6)$ \\
\hline $\begin{array}{l}\text { Para et al. } \\
\text { (North India) } \\
{[44]}\end{array}$ & $2013-15$ & 225 & $13(5.8)$ & 0 & 0 & 0 & $0(0.0)$ \\
\hline $\begin{array}{l}\text { Di Pasquale et al. } \\
\text { (GLOBAL) } \\
{[110]}\end{array}$ & 2015 & 3050 & 0 & 0 & $7(0.2)$ & 0 & $11(0.4)$ \\
\hline
\end{tabular}

$N R$ not reported

assume that the presence of virus isolates in nasopharyngeal swabs (as performed in most studies) is sufficient to explain CAP pathogenesis. Almost all studies (Table 3) using polymerase chain reaction (PCR) reported influenza, rhinovirus and respiratory syncytial virus (RSV) as the commonest isolated, but whether they are true pathogens remains debatable. Metapneumovirus was first described as a pathogen in children; however, it also infects adults, but the incidence is lower than in children [61]. Adults can carry the virus asymptomatically. However, it was recognized as a single CAP pathogen in $4 \%$ of patients in the USA [9] and recently had been implicated in severe CAP [61]. Similarly to other viruses, metapneumovirus appears to have a seasonal variation with a peak after influenza season.

Microbiology remains of utmost importance given that it has a significant prognostic impact.

\section{UNMET CLINICAL NEEDS}

CAP unmet clinical needs set priorities for research topics in CAP therapy and prevention through vaccines, that are, in our opinion, important to be perform in the next few years, 
Table 4 Unmet clinical needs in CAP

Therapy

What time is acceptable to start antibiotics in patients with CAP?

Why is evidence of short duration antibiotic therapy in CAP not applied in clinical management?

Which patients should be treated with antiviral therapy in CAP?

Should antiviral therapy be used empirically during influenza seasonal epidemics or all year?

Could PK/PD interventions change the outcomes in severe CAP?

In non-severe CAP might new oral antibiotics be directed to once-daily dosages?

What is the role of tetracyclines in CAP treatment?

In severe CAP what is the best drug on top of beta-lactam therapy: macrolide or quinolone?

Adjunctive therapies

Which patients will benefit from steroid therapy in CAP?

What are the best steroid, steroid dose and duration in CAP?

In patients with CAP presenting with high inflammatory response, can steroid therapy improve hard outcomes?

How should viral infection be excluded before steroid treatment?

Can steroids and macrolides have an addictive anti-inflammatory effect?

Is PCV13 superior to PPV23 in invasive pneumococcal disease and pneumococcal CAP?

Prevention

Which is the best scheme/schedule of anti-pneumococcal vaccination?

Is vaccine efficacy equivalent in immunocompetent and immunosuppressed patients?

Is adult pneumococcal vaccination cost-effective in settings with high childhood vaccination rates?

Will vaccines directed to $S$. pneumoniae virulence factors be more efficient than current ones?

Epidemiology

New randomized controlled trial (RCT) to study performance of new drugs in patients with severe CAP (PSI > 120, PORT class V)

Which is the epidemiology of lethal CAP?

What is the real burden of morbidity and mortality after CAP?

How should microbiologic surveillance be performed in a global way?

based on currently available evidence. The most important challenges in clinical research of CAP are listed in Table 4.

\section{Antibiotic Therapy}

In the last decade, many efforts were made to develop new drugs, resulting in newly approved antibiotics listed in Table 5. However, new antibiotics were often being developed to improve their activity against several MDR microorganisms, which are, as previously shown, uncommon in CAP. Most of these trials focused on patients with non-severe CAP requiring hospitalization [62-68], excluding severely ill patients (or ICU patients), so recommendations for these groups of patients are 
Table 5 New antibiotics for CAP treatment

\begin{tabular}{|c|c|c|}
\hline & Reported severity of patients included in trials & Dose and posology \\
\hline Ceftobiprole & $\begin{array}{l}\text { All hospitalized patients; PORT risk class V: } 1.7 \% \text { of } \\
\text { population study }^{\mathrm{a}}\end{array}$ & $500 \mathrm{mg}$, iv, $8 / 8 \mathrm{~h}, 2 \mathrm{~h}$ infusion \\
\hline Ceftaroline & $\begin{array}{l}\text { Only PORT risk class III or IV (not admitted to ICU on } \\
\text { recruitment) }\end{array}$ & $600 \mathrm{mg}$, iv, $12 / 12 \mathrm{~h}$ \\
\hline Omadacycline & PORT risk class II, III or IV & $\begin{array}{r}100 \mathrm{mg} \text {, iv, } 12 / 12 \mathrm{~h} \text { for } 2 \text { doses, followed by } \\
100 \mathrm{mg} \text {, iv, daily, or } 300 \mathrm{mg} \text {, orally, daily }\end{array}$ \\
\hline Delafloxacin & $\begin{array}{l}\text { PORT risk class II-V, excluding patients admitted to ICU } \\
\text { (not yet published) }\end{array}$ & $\begin{array}{l}300 \mathrm{mg} \text {, iv, } 12 / 12 \mathrm{~h} \text { or } 450 \mathrm{mg} \text {, orally, } \\
12 / 12 \mathrm{~h}\end{array}$ \\
\hline Solithromycin & PORT risk class II-IV in both trials & $\begin{array}{l}800 \mathrm{mg} \text { orally (or } 400 \mathrm{mg} \text { iv), on the first } \\
\text { day followed by } 400 \mathrm{mg} \text { orally or iv, daily }\end{array}$ \\
\hline Lefamulin & $\begin{array}{l}\text { (a) PORT risk class } \geq \text { III, excluding mechanically ventilated; } \\
\text { in PORT class III-V, not mechanically ventilated; } \\
\text { (b) PORT risk class II-IV }\end{array}$ & $\begin{array}{l}150 \mathrm{mg} \text {, iv, } 12 / 12 \mathrm{~h} \text { or } 600 \mathrm{mg} \text {, orally, } \\
12 / 12 \mathrm{~h}\end{array}$ \\
\hline
\end{tabular}

PORT Pneumonia Patient Outcomes Research Team, iv intravenous

${ }^{a}$ Ceftobiprole arm 1.2\% (4/314) and comparator arm $2.2 \%(7 / 329)$

derived from studies without their representation. It is an important limitation for the widespread use of new antibiotics, in spite of drug usage specificities in critically ill patients. Studies are needed in more severely ill patients. RCTs showing superiority instead of "non-inferiority" are needed to show a clear advantage of new drugs. In the period after introduction of new antibiotics, microbiological resistance surveillance remains essential because of new antibiotic pressure among pathogens, which could lead to resistance. Long-term side effects should also be studied.

\section{Adjunctive Therapies}

Several therapies have been tested to improve CAP outcomes using different strategies, to target innate immunity and adaptive immunity, as well as other immunomodulatory or anti-inflammatory drugs. For the purpose of this review we focus on adjunctive therapies to steroids and macrolides that are clinically available and the subject of many studies. Difficulties in showing an impact on hard outcomes, and difficulties in properly identifying the patients that will benefit more of them, impair the use of adjunctive therapies. Furthermore, as these therapies focus mainly on the inflammatory response, long-term outcome studies should be performed to analyze how they modulate long-term mortality that is related to chronic inflammatory status.

\section{Steroids}

The use of steroid therapy in patients with bacterial CAP remains uncertain, mainly because of the lack of knowledge about which phenotypes of disease and patient groups will have greater benefits from this therapy.

Inflammatory response contributes to CAP mortality. Steroid therapy reduces the inflammatory response and is therefore believed to improve outcomes in patients with CAP . However, this assumption remains controversial because of conflicting results regarding mortality [69-73]. Although it is likely to enhance patient performance, the published positive results focused on soft outcomes (reduction of treatment failure, length of stay, progression to acute respiratory distress 
syndrome, radiological progression and time to clinical stability) [69-73]. Steroid treatment depending on high inflammatory response should also be retested addressing hard endpoints [74] because the previous published RCT used radiological improvement as a primary outcome. The only study that established mortality as the primary outcome [75] has not yet been published. Precise identification of patients that will benefit from steroids is critical, given that these drugs have important side effects. Steroids have the potential to reduce survival in viral respiratory infections. The ideal method to convincingly exclude viral infection before steroid therapy initiation should also be addressed. For that, new studies are needed in specific populations (i.e. studying separately severe and non-severe CAP) to improve the body of evidence about steroid usage in CAP.

\section{Macrolide Therapy}

Macrolide therapy is used frequently in respiratory diseases for its antimicrobial activity and anti-inflammatory effects. Several in vitro and in vivo studies proved this ability through a reduction in pro-inflammatory interleukins and improved levels of anti-inflammatory ones, as well as the ability to reduce polymorphonuclear neutrophil (PMN) recruitment and decrease reactive oxygen species [76-80]. The clinical meaning of these findings remains controversial because, for now, there is no randomized clinical trial confirming the superiority of therapies containing macrolides regarding mortality [81, 82]. However, observational studies [83-86] showed consistently improved outcomes in invasive pneumococcal disease in severely ill patients (i.e. invasively ventilated and under vasopressor treatment). Some guidelines [87-90] recommend use of macrolides in combination therapy with betalactams as first-line therapy in CAP, either in ICU and non-ICU patients. Those recommendations were mainly driven by observational studies that are subject to bias. Evidence from recent RCTs [91], failed again to show the advantages of this approach in non-critically ill patients that had never been clearly shown. The generalized use of macrolides has the potential to promote antibiotic resistance, so until an RCT shows evidence of benefit macrolides should be judiciously used in non-critically ill patients, whereas macrolides are associated with QTc interval prolongation, gastrointestinal events and drug interactions.

\section{Vaccination}

Pneumococcal vaccination [92], where the vaccination rate is higher, contributes to pneumococcal vaccine-type disease reduction. Data regarding herd protection is not consensual, but its disparity could be explained by the different time intervals between generalized vaccination and studies [93, 94]. Further, vaccine introduction also leads to serotype shifting; meanwhile, no effects in resistance patterns were noted [95]. Several efforts were made to develop a vaccine to prevent pneumococcal infection resulting in two available vaccines: pneumococcal polysaccharide 23-valent (PPV23, contains capsular polysaccharides of $60 \%$ of serotypes causing disease in adults) and pneumococcal conjugate 13-valent (PCV13, stimulates antibody production against $28-42 \%$ of serotypes causing disease, varying according different geographical areas). For both, vaccine efficacy has been proven for invasive pneumococcal disease $[96,97]$. Only PCV13 has been clearly associated with the prevention of non-invasive and invasive pneumococcal community-acquired pneumonia (CAPiTA trial [97]) regarding vaccine-targeted serotypes. In different countries, vaccine indications vary, some based on believing that PCV13 could boost immunity created by PPV23 (when previously administered) [98]. It is controversial whether PCV13 is superior to PPV23, because comparative trials are lacking. New outcomes should also be determined for invasive pneumococcal disease and pneumococcal $\mathrm{CAP}$, as well as all-cause mortality and pneumococcal CAP-related mortality. The definition of immunosuppressed patients also varies according to different studies, which impairs the process of studying real immunosuppressive risk factors for pneumococcal infection. 
Table 6 Pneumococcal vaccine indications and described vaccine efficacy

\begin{tabular}{lll}
\hline & Pneumococcal polysaccharide 23-valent & $\begin{array}{l}\text { Pneumococcal conjugate } \\
\text { 13-valent }\end{array}$ \\
\hline Serotypes included & $\begin{array}{l}1,2,3,4,5,6 \mathrm{~B}, 7 \mathrm{~F}, 8,9 \mathrm{~N}, 9 \mathrm{~V}, 10 \mathrm{~A}, 11 \mathrm{~A}, 12 \mathrm{~F}, 14,15 \mathrm{~B}, 17 \mathrm{~F}, 1,3,4,5,6 \mathrm{~A}, 6 \mathrm{~B}, 7 \mathrm{~F}, 9 \mathrm{~V}, 14, \\
18 \mathrm{C}, 19 \mathrm{~F}, 19 \mathrm{~A}, 20,22 \mathrm{~F}, 23 \mathrm{~F} \text { and } 33 \mathrm{~F}\end{array}$ \\
$\begin{array}{l}\text { Vaccine efficacy [97] } \\
\text { IPD }\end{array}$ & $60.0 \%$ & $79 \mathrm{~A}, 19 \mathrm{~F}$ and 23F \\
PCAP & $63.8 \%$ & $45.6 \%$ \\
Vaccine indications & & \\
Immunocompromised & $\begin{array}{l}\text { HIV, nephrotic syndrome, chronic kidney disease, immunodeficiency (congenital and acquired), } \\
\text { metastatic cancer, lymphoma, leukaemia, Hodgkin disease, multiple myeloma, transplanted, }\end{array}$ \\
& immunosuppressed & \\
& Asplenia (functional and anatomical): congenital, acquired and haemoglobinopathies
\end{tabular}

$I P D$ invasive pneumococcal disease, PCAP pneumococcal community-acquired pneumonia

${ }^{a}$ (Dependent of country policy) chronic heart, lung or liver disease, diabetes mellitus, smoking, alcohol use disorder

While in immunocompromised patients indications for vaccination are well established (Table 6), in other groups evidence is less clear, allowing different recommendations in different countries. Pneumococcal vaccine calendar, administration of one or both vaccines [99], should be further elucidated in new studies. After introduction of vaccines, pneumococcal microbiology in CAP moved to serotypes that are not included in vaccines [95]. New vaccines immunizing widely for other serotypes will be valuable, as well as other vaccine approaches targeting S. pneumoniae virulence factors. Costeffectiveness of vaccination in adults should be evaluated to analyze whether high child pneumococcal immunization could modify its costeffectiveness in adults and the elderly.

\section{CONCLUSION}

The large body of evidence discussed has exposed the high incidence and mortality of CAP, usually related to older age and co-morbidities. CAP microbiology had been changed because new diagnostic tests have turned viruses into the most identified pathogens, while their role in pathogenesis is not fully explained. Adjunctive therapies should remain part of CAP tailored management. Vaccines should remain the backbone of bacterial CAP prevention. Further studies are needed to improve outcomes in patients with CAP.

\section{ACKNOWLEDGEMENTS}

Funding. No funding or sponsorship was received for this study or publication of this article.

Authorship. All named authors meet the International Committee of Medical Journal Editors (ICMJE) criteria for authorship for this article, take responsibility for the integrity of the work as a whole, and have given their approval for this version to be published.

Disclosures. João Ferreira-Coimbra and Cristina Sarda have no conflicts of interest. Jordi Rello was Nabriva advisor. Jordi Rello is a member of the journal's Editorial Board. 
Compliance with Ethics Guidelines. This article is based on previously conducted studies and does not contain any studies with human participants or animals performed by any of the authors.

Open Access. This article is licensed under a Creative Commons Attribution-NonCommercial 4.0 International License, which permits any non-commercial use, sharing, adaptation, distribution and reproduction in any medium or format, as long as you give appropriate credit to the original author(s) and the source, provide a link to the Creative Commons licence, and indicate if changes were made. The images or other third party material in this article are included in the article's Creative Commons licence, unless indicated otherwise in a credit line to the material. If material is not included in the article's Creative Commons licence and your intended use is not permitted by statutory regulation or exceeds the permitted use, you will need to obtain permission directly from the copyright holder. To view a copy of this licence, visit http:// creativecommons.org/licenses/by-nc/4.0/.

\section{REFERENCES}

1. World Health Organization. Global health estimates 2016: disease burden by cause, age, sex, by country and by region, 2000-2016. Geneva; 2018.

2. Kalil AC, Metersky ML, Klompas M, et al. Management of adults with hospital-acquired and ventilator-associated pneumonia: 2016 clinical practice guidelines by the Infectious Diseases Society of America and the American Thoracic Society. Clin Infect Dis. 2016;63(5):e61-111.

3. Dedrick RM, Guerrero-Bustamante CA, Garlena RA, et al. Engineered bacteriophages for treatment of a patient with a disseminated drug-resistant $M y$ cobacterium abscessus. Nat Med. 2019;25:730-3.

4. Laterre PF, Colin G, Dequin PF, et al. CAL02, a novel antitoxin liposomal agent, in severe pneumococcal pneumonia: a first-in-human, double-blind, placebo-controlled, randomised trial. Lancet Infect Dis. $2019 ; 19(6): 620-30$.

5. Bjarnason A, Westin J, Lindh $\mathrm{M}$, et al. Incidence, etiology, and outcomes of community-acquired pneumonia: a population-based study. Open Forum Infect Dis. 2018;5(2):ofy010.

6. Millett ER, Quint JK, Smeeth L, Daniel RM, Thomas SL. Incidence of community-acquired lower respiratory tract infections and pneumonia among older adults in the United Kingdom: a population-based study. PLoS One. 2013;8(9):e75131.

7. Sterrantino C, Trifirò G, Lapi F, et al. Burden of community-acquired pneumonia in Italian general practice. Eur Respir J. 2013;42(6):1739-42.

8. Partouche H, Lepoutre A, Vaure CBD, Poisson T, Toubiana L, Gilberg S. Incidence of all-cause adult community-acquired pneumonia in primary care settings in France. Med Mal Infect. 2018;48(6): 389-95.

9. Jain S, Self WH, Wunderink RG, et al. Communityacquired pneumonia requiring hospitalization among U.S. adults. N Engl J Med. 2015;373(5): 415-27.

10. Broulette J, Yu H, Pyenson B, Iwasaki K, Sato R. The incidence rate and economic burden of community-acquired pneumonia in a working-age population. Am Health Drug Benefits. 2013;6(8):494-503.

11. Lopardo GD, Fridman D, Raimondo E, et al. Incidence rate of community-acquired pneumonia in adults: a population-based prospective active surveillance study in three cities in South America. BMJ Open. 2018;8(4):e019439.

12. Buzzo AR, Roberts C, Mollinedo LG, Quevedo JM, Casas GL, Soldevilla JM. Morbidity and mortality of pneumonia in adults in six Latin American countries. Int J Infect Dis. 2013;17(9):e673-7.

13. Choi MJ, Song JY, Noh JY, et al. Disease burden of hospitalized community-acquired pneumonia in South Korea: analysis based on age and underlying medical conditions. Medicine (Baltimore). 2017;96(44):e8429.

14. Heo JY, Song JY. Disease burden and etiologic distribution of community-acquired pneumonia in adults: evolving epidemiology in the era of pneumococcal conjugate vaccines. Infect Chemother. 2018;50(4):287-300.

15. Azmi S, Aljunid SM, Maimaiti N, et al. Assessing the burden of pneumonia using administrative data from Malaysia, Indonesia, and the Philippines. Int J Infect Dis. 2016;49:87-93.

16. Zhu YG, Tang XD, Lu YT, Zhang J, Qu JM. Contemporary situation of community-acquired pneumonia in china: a systematic review. J Transl Int Med. 2018;6(1):26-31. https://doi.org/10.2478/ jtim-2018-0006. 
17. Sharma S, Sneath E, Friedman ND, Cheng AC. Community-acquired syndromes causing morbidity and mortality in Australia. Commun Dis Intell Q Rep. 2017;41(1):E49-57.

18. Li A, Newall AT, Britt H, Macintyre CR. The cost and disease burden of pneumonia in general practice in Australia. Vaccine. 2012;30(5):830-1.

19. Song JH, Thamlikitkul V, Hsueh PR. Clinical and economic burden of community-acquired pneumonia amongst adults in the Asia-Pacific region. Int J Antimicrob Agents. 2011;38(2):108-17.

20. Rozenbaum MH, Mangen MJ, Huijts SM, van der Werf TS, Postma MJ. Incidence, direct costs and duration of hospitalization of patients hospitalized with community acquired pneumonia: a nationwide retrospective claims database analysis. Vaccine. 2015;33(28):3193-9.

21. Almirall J, Bolíbar I, Vidal J, et al. Epidemiology of community-acquired pneumonia in adults: a population-based study. Eur Respir J. 2000;15(4): 757-63.

22. Welte T, Torres A, Nathwani D. Clinical and economic burden of community-acquired pneumonia among adults in Europe. Thorax. 2012;67(1):71-9.

23. Marrie TJ, Huang JQ. Epidemiology of communityacquired pneumonia in Edmonton, Alberta: an emergency department-based study. Can Respir J. 2005;12(3):139-42.

24. World Health Organization. Disease burden and mortality estimates. 2000-2016, June 2018, Geneva. https://www.who.int/healthinfo/global_burden disease/estimates/en/index1.html. Accessed 24 June 2019

25. Lozano R, Naghavi M, Foreman K, et al. Global and regional mortality from 235 causes of death for 20 age groups in 1990 and 2010: a systematic analysis for the Global Burden of Disease Study 2010. Lancet. 2012;380(9859):2095-128.

26. Ramirez JA, Wiemken TL, Peyrani P, et al. Adults hospitalized with pneumonia in the United States: incidence, epidemiology, and mortality. Clin Infect Dis. 2017;65(11):1806-12.

27. Gibson GJ, Loddenkemper R, Lundbäck B, Sibille Y. Respiratory health and disease in Europe: the new European Lung White Book. Eur Respir J. 2013;42(3):559-63.

28. Johnstone J, Eurich DT, Majumdar SR, Jin Y, Marrie TJ. Long-term morbidity and mortality after hospitalization with community-acquired pneumonia: a population-based cohort study. Medicine (Baltimore). 2008;87(6):329-34.
29. Song JH, Huh K, Chung DR. Community-acquired pneumonia in the Asia-Pacific region. Semin Respir Crit Care Med. 2016;37(6):839-54.

30. Aston SJ. Pneumonia in the developing world: characteristic features and approach to management. Respirology. 2017;22(7):1276-87.

31. Teixeira-Lopes F, Cysneiros A, Dias A, et al. Intrahospital mortality for community-acquired pneumonia in mainland Portugal between 2000 and 2009. Pulmonology. 2019;25(2):66-70.

32. Rello J, Perez A. Precision medicine for the treatment of severe pneumonia in intensive care. Expert Rev Respir Med. 2016;10(3):297-316.

33. Ranzani OT, Prina E, Menéndez R, et al. New sepsis definition (Sepsis-3) and community-acquired pneumonia mortality. A validation and clinical decision-making study. Am J Respir Crit Care Med. 2017;196(10):1287-97.

34. Vallés J, Diaz E, Martín-Loeches I, et al. Evolution over a 15-year period of the clinical characteristics and outcomes of critically ill patients with severe community-acquired pneumonia. Med Intensiva. 2016;40(4):238-45.

35. Ramirez JA, Anzueto AR. Changing needs of community-acquired pneumonia. J Antimicrob Chemother. 2011;66(Suppl 3):iii3-9.

36. Daniel P, Woodhead M, Welham S, Mckeever TM, Lim WS, British Thoracic Society. Mortality reduction in adult community-acquired pneumonia in the UK (2009-2014): results from the British Thoracic Society audit programme. Thorax. 2016;71(11):1061-3.

37. Cillóniz C, Ewig S, Polverino E, et al. Communityacquired pneumonia in outpatients: aetiology and outcomes. Eur Respir J. 2012;40(4):931-8.

38. Musher DM, Abers MS, Bartlett JG. Evolving understanding of the causes of pneumonia in adults, with special attention to the role of Pneumococcus. Clin Infect Dis. 2017;65(10):1736-44.

39. Johansson N, Kalin M, Tiveljung-Lindell A, Giske CG, Hedlund J. Etiology of community-acquired pneumonia: increased microbiological yield with new diagnostic methods. Clin Infect Dis. 2010;50(2):202-9.

40. Gadsby NJ, Russell CD, McHugh MP, et al. Comprehensive molecular testing for respiratory pathogens in community-acquired pneumonia. Clin Infect Dis. 2016;62(7):817-23.

41. Lui G, Ip M, Lee N, et al. Role of 'atypical pathogens' among adult hospitalized patients with 
community-acquired pneumonia. Respirology. 2009;14(8):1098-105.

42. Sahuquillo-Arce JM, Menéndez R, Méndez R, et al. Age-related risk factors for bacterial aetiology in community-acquired pneumonia. Respirology. 2016;21(8):1472-9.

43. Song JH, Oh WS, Kang CI, et al. Epidemiology and clinical outcomes of community-acquired pneumonia in adult patients in Asian countries: a prospective study by the Asian network for surveillance of resistant pathogens. Int J Antimicrob Agents. 2008;31(2):107-14.

44. Para RA, Fomda BA, Jan RA, Shah S, Koul PA. Microbial etiology in hospitalized North Indian adults with community-acquired pneumonia. Lung India. 2018;35(2):108-15.

45. van Deursen VM, Damman K, Hillege HL, van Beek AP, van Veldhuisen DJ, Voors AA. Abnormal liver function in relation to hemodynamic profile in heart failure patients. J Card Fail. 2010;16(1):84-90.

46. Dagaonkar RS, Udwadia ZF, Sen T, et al. Severe community acquired pneumonia in Mumbai, India: etiology and predictive value of the modified British Thoracic Society rule. Am J Respir Crit Care Med. 2012;185:A6060.

47. Isturiz RE, Luna CM, Ramirez J. Clinical and economic burden of pneumonia among adults in Latin America. Int J Infect Dis. 2010;14(10):e852-6.

48. Arnold FW, Summersgill JT, Lajoie AS, et al. A worldwide perspective of atypical pathogens in community-acquired pneumonia. Am J Respir Crit Care Med. 2007;175(10):1086-93.

49. Shindo Y, Ito R, Kobayashi D, et al. Risk factors for drug-resistant pathogens in community-acquired and healthcare-associated pneumonia. Am J Respir Crit Care Med. 2013;188(8):985-95.

50. Cao B, Ren LL, Zhao F, et al. Viral and Mycoplasma pneumoniae community-acquired pneumonia and novel clinical outcome evaluation in ambulatory adult patients in China. Eur J Clin Microbiol Infect Dis. 2010;29(11):1443-8.

51. Tacconelli E, Carrara E, Savoldi A, et al. Discovery,research, and development of new antibiotics: the WHO priority list of antibiotic-resistant bacteriaand tuberculosis. Lancet Infect Dis. 2018;18(3): $318-27$.

52. Patra S, Shaw T, Eshwara VK, Saravu K, Hande M, Mukhopadhyay C. Pulmonary melioidosis: an experience over years from a tertiary care hospital from southwest India. Indian J Med Sci Vol. 2017;69(3):21-6.
53. Meumann EM, Cheng AC, Ward L, Currie BJ. Clinical features and epidemiology of melioidosis pneumonia: results from a 21-year study and review of the literature. Clin Infect Dis. 2012;54(3):362-9.

54. Benoit TJ, Blaney DD, Gee JE, et al. Melioidosis cases and selected reports of occupational exposures to Burkholderia pseudomallei-United States, 2008-2013. MMWR Surveill Summ. 2015;64(5):1-9.

55. Le Tohic S, Montana M, Koch L, Curti C, Vanelle P. A review of melioidosis cases imported into Europe. Eur J Clin Microbiol Infect Dis. 2019;38(8): 1395-408.

56. Restrepo MI, Babu BL, Reyes LF, et al. Burden and risk factors for Pseudomonas aeruginosa communityacquired pneumonia: a multinational point prevalence study of hospitalised patients. Eur Respir J. 2018;52(2):1701190.

57. Aliberti S, Reyes LF, Faverio P, et al. Global initiative for meticillin-resistant Staphylococcus aureus pneumonia (GLIMP): an international, observational cohort study. Lancet Infect Dis. 2016;16(12): 1364-76.

58. Wu X, Wang Q, Wang M, et al. Incidence of respiratory viral infections detected by PCR and realtime PCR in adult patients with community-acquired pneumonia: a meta-analysis. Respiration. 2015;89(4):343-52.

59. Alimi Y, Lim WS, Lansbury L, Leonardi-Bee J, Nguyen-Van-Tam JS. Systematic review of respiratory viral pathogens identified in adults with community-acquired pneumonia in Europe. J Clin Virol. 2017;95:26-35.

60. Burk M, El-Kersh K, Saad M, Wiemken T, Ramirez J, Cavallazzi R. Viral infection in community-acquired pneumonia: a systematic review and meta-analysis. Eur Respir Rev. 2016;25(140):178-88.

61. Vidaur L, Totorika I, Montes M, Vicente D, Rello J, Cilla G. Human metapneumovirus as cause of severe community-acquired pneumonia in adults: insights from a ten-year molecular and epidemiological analysis. Ann Intensive Care. 2019;9(1):86.

62. ClinicalTrials.gov. Study to compare delafloxacin to moxifloxacin for the treatment of adults with community-acquired bacterial pneumonia (DEFINE-CABP). https://clinicaltrials.gov/ct2/show/ NCT02679573?term=delafloxacin\&cond=pneumonia\& rank=1. 2016. Accessed June 21, 2019.

63. File TM Jr, Rewerska B, Vucinic-Mihailovic V, et al. SOLITAIRE-IV: a randomized, double-blind, multicenter study comparing the efficacy and safety of intravenous-to-oral solithromycin to intravenousto-oral moxifloxacin for treatment of community- 
acquired bacterial pneumonia. Clin Infect Dis. 2016;63(8):1007-16.

64. Barrera CM, Mykietiuk A, Metev H, et al. Efficacy and safety of oral solithromycin versus oral moxifloxacin for treatment of community-acquired bacterial pneumonia: a global, double-blind, multicentre, randomised, active-controlled, noninferiority trial (SOLITAIRE-ORAL). Lancet Infect Dis. 2016;16(4):421-30.

65. Low DE, File TM Jr, Eckburg PB, et al. FOCUS 2: a randomized, double-blinded, multicentre, phase III trial of the efficacy and safety of ceftaroline fosamil versus ceftriaxone in community-acquired pneumonia. J Antimicrob Chemother. 2011;66(Suppl 3): iii33-44.

66. Nicholson SC, Welte T, File TM Jr, et al. A randomised, double-blind trial comparing ceftobiprole medocaril with ceftriaxone with or without linezolid for the treatment of patients with communityacquired pneumonia requiring hospitalisation. Int J Antimicrob Agents. 2012;39(3):240-6.

67. File TM, Goldberg L, Das A, et al. Efficacy and safety of intravenous-to-oral lefamulin, a pleuromutilin antibiotic, for the treatment of community-acquired bacterial pneumonia: the phase III lefamulin evaluation against pneumonia (LEAP 1) trial. Clin Infect Dis. 2019;69(11):1856-67.

68. Stets R, Popescu M, Gonong JR, et al. Omadacycline for community-acquired bacterial pneumonia. N Engl J Med. 2019;380(6):517-27.

69. Snijders D, Daniels JM, de Graaff CS, van der Werf TS, Boersma WG. Efficacy of corticosteroids in community-acquired pneumonia: a randomized double-blinded clinical trial. Am J Respir Crit Care Med. 2010;181(9):975-82.

70. Meijvis SC, Hardeman $\mathrm{H}$, Remmelts $\mathrm{HH}$, et al. Dexamethasone and length of hospital stay in patients with community-acquired pneumonia: a randomised, double-blind, placebo-controlled trial. Lancet. 2011;377(9782):2023-30.

71. Confalonieri M, Urbino R, Potena A, et al. Hydrocortisone infusion for severe community-acquired pneumonia: a preliminary randomized study. Am J Respir Crit Care Med. 2005;171(3):242-8.

72. Blum CA, Nigro N, Briel M, et al. Adjunct prednisone therapy for patients with community-acquired pneumonia: a multicentre, double-blind, randomised, placebo-controlled trial. Lancet. 2015;385(9977):1511-8.

73. Fernández-Serrano S, Dorca J, Garcia-Vidal C, et al. Effect of corticosteroids on the clinical course of community-acquired pneumonia: a randomized controlled trial. Crit Care. 2011;15(2):R96.

74. Torres A, Sibila O, Ferrer M, et al. Effect of corticosteroids on treatment failure among hospitalized patients with severe community-acquired pneumonia and high inflammatory response: a randomized clinical trial. JAMA. 2015;313(7):677-86.

75. ClinicalTrials.gov. Evaluate the safety and efficacy of methylprednisolone in hospitalized veterans with severe community-acquired pneumonia. https://clinicaltrials.gov/ct2/show/NCT01283009. 2011. Accessed June 21, 2019.

76. Duong M, Simard M, Bergeron Y, Ouellet N, CôtéRicher M, Bergeron MG. Immunomodulating effects of HMR 3004 on pulmonary inflammation caused by heat-killed Streptococcus pneumoniae in mice. Antimicrob Agents Chemother. 1998;42(12): 3309-12.

77. Yasuda Y, Kasahara K, Mizuno F, Nishi K, Mikasa K, Kita E. Roxithromycin favorably modifies the initial phase of resistance against infection with macrolide-resistant Streptococcus pneumoniae in a murine pneumonia model. Antimicrob Agents Chemother. 2007;51(5):1741-52.

78. Duong M, Simard M, Bergeron Y, Bergeron MG. Kinetic study of the inflammatory response in Streptococcus pneumoniae experimental pneumonia treated with the ketolide HMR 3004. Antimicrob Agents Chemother. 2001;45(1):252-62.

79. Leiva M, Ruiz-Bravo A, Jimenez-Valera M. Effects of telithromycin in in vitro and in vivo models of lipopolysaccharide-induced airway inflammation. Chest. 2008;134(1):20-9.

80. Demartini G, Esposti D, Marthyn P, Lapidari A, Fraschini F, Scaglione F. Effect of multiple doses of clarithromycin and amoxicillin on IL-6, IFNgamma and IL-10 plasma levels in patients with community acquired pneumonia. J Chemother. 2004;16(1): $82-5$.

81. Garin N, Genné D, Carballo S, et al. $\beta$-Lactam monotherapy vs $\beta$-lactam-macrolide combination treatment in moderately severe community-acquired pneumonia: a randomized noninferiority trial. JAMA Intern Med. 2014;174(12):1894-901.

82. Postma DF, van Werkhoven $\mathrm{CH}$, Huijts SM, Bolkenbaas M, Oosterheert JJ, Bonten MJ. New trends in the prevention and management of community-acquired pneumonia. Neth J Med. 2012;70(8):337-48.

83. Baddour LM, Yu VL, Klugman KP, et al. Combination antibiotic therapy lowers mortality among 
severely ill patients with pneumococcal bacteremia. Am J Respir Crit Care Med. 2004;170(4):440-4.

84. Mortensen EM, Halm EA, Pugh MJ, et al. Association of azithromycin with mortality and cardiovascular events among older patients hospitalized with pneumonia. JAMA. 2014;311(21):2199-208.

85. Restrepo MI, Mortensen EM, Waterer GW, Wunderink RG, Coalson JJ, Anzueto A. Impact of macrolide therapy on mortality for patients with severe sepsis due to pneumonia. Eur Respir J. 2009;33(1): 153-9.

86. Martin-Loeches I, Lisboa T, Rodriguez A, et al. Combination antibiotic therapy with macrolides improves survival in intubated patients with community-acquired pneumonia. Intensive Care Med. 2010;36(4):612-20.

87. Mandell LA, Wunderink RG, Anzueto A, et al. Infectious Diseases Society of America/American Thoracic Society consensus guidelines on the management of community-acquired pneumonia in adults. Clin Infect Dis. 2007;44(Suppl 2):S27-72.

88. Woodhead M, Blasi F, Ewig S, et al. Guidelines for the management of adult lower respiratory tract infections-full version. Clin Microbiol Infect. 2011;17(Suppl 6):E1-59.

89. Corrêa RA, Costa AN, Lundgren F, et al. 2018 recommendations for the management of community acquired pneumonia . J Bras Pneumol. 2018;44(5): 405-23. (Published correction appears in $\mathrm{J}$ Bras Pneumol. 2018 Nov-Dec;44(6):532).

90. Menéndez R, Torres A, Aspa J, et al. Community acquired pneumonia. New guidelines of the Spanish Society of Chest Diseases and Thoracic Surgery (SEPAR). Arch Bronconeumol. 2010;46(10):543-58.

91. Postma DF, van Werkhoven $\mathrm{CH}$, van Elden LJ, et al. Antibiotic treatment strategies for community-acquired pneumonia in adults. $\mathrm{N}$ Engl $\mathrm{J}$ Med. 2015;372(14):1312-23.

92. Pilishvili T, Lexau C, Farley MM, et al. Sustained reductions in invasive pneumococcal disease in the era of conjugate vaccine. J Infect Dis. 2010;201(1): $32-41$.

93. Shiri T, Datta S, Madan J, et al. Indirect effects of childhood pneumococcal conjugate vaccination on invasive pneumococcal disease: a systematic review and meta-analysis. Lancet Glob Health. 2017;5(1): e51-9.

94. Menéndez R, España PP, Pérez-Trallero E, et al. The burden of PCV13 serotypes in hospitalized pneumococcal pneumonia in Spain using a novel urinary antigen detection test. CAPA study. Vaccine. 2017;35(39):5264-70.

95. Richter SS, Diekema DJ, Heilmann KP, Dohrn CL, Riahi F, Doern GV. Changes in pneumococcal serotypes and antimicrobial resistance after introduction of the 13-valent conjugate vaccine in the United States. Antimicrob Agents Chemother. 2014;58(11):6484-9.

96. Moberley S, Holden J, Tatham DP, Andrews RM. Vaccines for preventing pneumococcal infection in adults. Cochrane Database Syst Rev. 2013;(1): CD000422.

97. Bonten MJ, Huijts SM, Bolkenbaas $M$, et al. Polysaccharide conjugate vaccine against pneumococcal pneumonia in adults. $\mathrm{N}$ Engl $\mathrm{J}$ Med. 2015;372(12):1114-25.

98. Greenberg RN, Gurtman A, Frenck RW, et al. Sequential administration of 13-valent pneumococcal conjugate vaccine and 23-valent pneumococcal polysaccharide vaccine in pneumococcal vaccine-naïve adults 60-64 years of age. Vaccine. 2014;32(20):2364-74.

99. van Werkhoven CH, Huijts SM. Vaccines to prevent pneumococcal community-acquired pneumonia. Clin Chest Med. 2018;39(4):733-52.

100. Torres A, Peetermans WE, Viegi G, Blasi F. Risk factors for community-acquired pneumonia in adults in Europe: a literature review. Thorax. 2013;68(11):1057-65.

101. Rivero-Calle I, Pardo-Seco J, Aldaz P, et al. Incidence and risk factor prevalence of community-acquired pneumonia in adults in primary care in Spain (NEUMO-ES-RISK project). BMC Infect Dis. 2016;16(1):645.

102. Kolditz M, Tesch F, Mocke L, Höffken G, Ewig S, Schmitt J. Burden and risk factors of ambulatory or hospitalized CAP: a population based cohort study. Respir Med. 2016;121:32-8.

103. Corrado RE, Lee D, Lucero DE, Varma JK, Vora NM. Burden of adult community-acquired, health-careassociated, hospital-acquired, and ventilator-associated pneumonia: New York City, 2010 to 2014. Chest. 2017;152(5):930-42.

104. Scott G, Scott H, Turley M, Baker M. Economic cost of community-acquired pneumonia in New Zealand adults. N Z Med J. 2004;117(1196):U933.

105. Morimoto K, Suzuki M, Ishifuji T, et al. The burden and etiology of community-onset pneumonia in the aging Japanese population: a multicenter prospective study. PLoS One. 2015;10(3):e0122247. 
106. Heo JY, Seo YB, Choi WS, et al. Incidence and case fatality rates of community-acquired pneumonia and pneumococcal diseases among Korean adults: catchment population-based analysis. PLoS One. 2018;13(3):e0194598.

107. Poulose V. Severe community-acquired pneumonia requiring intensive care: a study of 80 cases from Singapore. Singap Med J. 2008;49(6):458-61.

108. Seo H, Cha SI, Shin KM, et al. Relationship between clinical features and computed tomographic findings in hospitalized adult patients with community- acquired pneumonia. Am J Med Sci. 2018;356(1): $30-8$.

109. Aston SJ, Ho A, Jary H, et al. Etiology and risk factors for mortality in an adult community-acquired pneumonia cohort in Malawi. Am J Respir Crit Care Med. 2019;200(3):359-69.

110. Di Pasquale MF, Sotgiu G, Gramegna A, et al. Prevalence and etiology of community-acquired pneumonia in immunocompromised patients. Clin Infect Dis. 2019;68(9):1482-93. 